\title{
SIMULATING STRESS CONDITION THROUGH COMPACTION IN BANANA PLANT CULTIVATED IN VITRO
}

\author{
SIMULAÇÃO DE ESTRESSE POR COMPACTAÇÃO EM BANANEIRAS \\ CULTIVADAS IN VITRO
}

\begin{abstract}
Mirielle de Oliveira ALMEIDA ${ }^{1}$; Dalilhia Nazaré dos SANTOS ${ }^{2}$; Adalvan Daniel MARTINS ${ }^{3}$; Leila Aparecida Salles PIO ${ }^{3}$; José Magno Queiroz LUZ ${ }^{4}$; Moacir Pasqual ${ }^{3}$; Tesfahun Alemu SETOTAW ${ }^{3}$; Mylena Chaves CARVALHO ${ }^{3}$

1. Empresa de Pesquisa Agropecuária e Extensão Rural de Santa Catarina; Sombrio, SC, Brasil. miriellealmeida@epagri.sc.gov.br; 2. Empresa Mato-Grossense de Pesquisa, Assistência e Extensão Rural, Cuiabá, MT, Brasil; 3Universidade Federal de Lavras (UFLA), Lavras, MG, Brasil; ${ }^{4}$ Universidade Federal de Uberlândia, Uberlândia, MG, Brasil.
\end{abstract}

\begin{abstract}
Banana cultivation is an agricultural activity practiced in different regions and constantly subjected to abiotic stresses that limit its productivity. To treat the effect of these stresses research can be undertake by simulating them in vitro since it limit the effect of the external factor in the experiment. Therefore, the objective of this study was to simulate the compaction in banana plant cultivated in vitro using Phytagel. To realize the experiment, we used MS culture medium with two distinct consistency added in the testing tubes. In the bottom part was added $10 \mathrm{~mL}$ of culture medium with consistency of jellification: 1.8, 2.8, 3.8, 4.8 and $5.8 \mathrm{~g} \mathrm{~L}^{-1}$ of Phytagel. Over this culture medium was added $5 \mathrm{~mL}$ of half MS with consistency standard $1.8 \mathrm{~g} \mathrm{~L}^{-1}$ of Phytagel. Posteriorly, the planting materials from cultivar Grand Naine, BRS Vitória and BRS Princesa were inoculated in the growth medium. After 30 days of culture the plant materials were submitted for agronomic and physiological evaluation. The result showed non-significant difference among the compaction factors on physiological parameters however variety Grand Naine presents better performance in this character. Besides variety Grand Naine increased the rate of photosynthesis under compaction. This behaviour probably occurred due to overcoming the effect of stress by the variety. Therefore, it can be concluded that the cultivar Grand Naine is superior to cultivars BRS Vitória and BRS Princesa since it produces superior performance on rate of photosynthesis, stomatal conductance, and transpiration under simulated compaction conditions that favor the accumulation of plant biomass.
\end{abstract}

KEYWORDS: Musa sp. Abiotic stress. Tissue culture. Phytagel

\section{INTRODUCTION}

According to Ravi and Vaganan (2016), the banana plant is a basic food crop cultivated worldwide and its principal production constraints are biotic and abiotic stresses that causes yield reduction in the field. According to the same authors, research works on biotic stresses has got attention all over the world whereas abiotic stress still in few.

The research activities with abiotic stresses are traditionally conducted in situ. However, screening a determined stress in the field is laborious. This is because it is impossible to control different variables interfering the characteristics of open ecosystem. Therefore, the modality of in vitro culture can contribute by providing pure effect in a determined abiotic stress conditions. Lawlor (2013) explained that in vitro stress simulation provides total control over the stress level and variability.

According to Clayes et al. (2004), the in vitro simulation of abiotic stresses is common and frequently used to simulate the stress occurred on plants in the field. Currently, most of the knowledge about the stress physiology comes in in vitro culture of Arabidopsis thaliana that resulted in the identification of many genes that increase the stress tolerance and influenced the researches all other plant species (GILL; TUTEJA, 2010; CLAYES et al., 2014).

The compaction stress is among abiotic stresses commonly affecting Musa sp. According to Champion (1963) the absence of compaction in the upper layer of the soil is the basic factor to be considered for the soil to be appropriate for banana cultivation. Such exigency placed due to the root system of Musa ap grown superficially, and $90 \%$ of the root biomass concentrated within the first $20 \mathrm{~cm}$ of the soil (GODEFROY, 1969). According to Silva (2006) in compacted soil, the root system of Musa sp became more superficial.

Although it is prejudicial, the literature about the effect of compaction in Musa sp is rare that demonstrate the necessity of information to limit its impact in banana cultivation. Therefore, the objective of this work was simulated compaction in 
vitro through manipulation of culture medium consistency using the banana cultivars Grand Naine, BRS Vitória and BRS Princesa.

\section{MATERIAL AND METHODS}

The banana cultivars Grand Naine, BRS Vitória and BRS Princesa were used in this study. These cultivars represented the banana types widely distributed and cultivated over the country. Besides the cultivars also represent nanica, prata and maça types of banana (EMBRAPA 2003, EMBRAPA 2005, EMBRAPA 2008).

The propagule of the cultivars was obtained from Embrapa (Cruz das Almas, BA) and cultivated in vitro for two generations to obtain sufficient buds to realize the experiment. The cultivation was realized in MS culture medium (MURASHIGE; SKOOG, 1962) supplemented with $30 \mathrm{~g} \mathrm{~L}^{-1}$ of sucrose and $3.75 \mathrm{mg} \mathrm{L}^{-1}$ of benzilaminopurina (BAP), $0.175 \mathrm{mg} \mathrm{L}^{-1}$ of indolactic acid (AIA) at $\mathrm{pH}$ 6.0 .

To establish the experiment the culture medium referred above was added in test tubes with two distinct consistencies. In the lower part of the tube was added $10 \mathrm{~mL}$ of medium with different level of compaction formed using different doses of Phytagel: $1.8 ; 2.8 ; 3.8 ; 4.8$ and $5.8 \mathrm{~g} \mathrm{~L}^{-1}$. Over this culture medium with different concentration of Phytagel were added $5 \mathrm{~mL}$ of culture medium with consistency of standard jellification of MS, that is $1.8 \mathrm{~g} \mathrm{~L}^{-1}$ of Phytagel. Therefore, the concentration of $1.8 \mathrm{~g} \mathrm{~L} \mathrm{~L}^{-1}$ Phytagel combined at the same concentration, ie $1.8 \mathrm{~g} \mathrm{~L}^{-1}$ Phytagel, was set up as the control treatment.

The experiment was established using completely randomized experimental design in $3 \times 5$ factors. The combinations were three cultivars (Grand Naine, Vitória and Princesa) and five doses of Phytagel $\left(1.8 ; 2.8 ; 3.8 ; 4.8\right.$ and $\left.5.8 \mathrm{~g} \mathrm{~L}^{-1}\right)$ with nine tubes per plot. Then the plant material remained in growth room with light intensity of 36 $\mu \mathrm{mol} \mathrm{m} \mathrm{m}^{-2} \mathrm{~s}^{-1}, 16$ hours' photoperiod and temperature of $25 \pm 2^{\circ} \mathrm{C}$. After 30 days of culture the experiment were subjected of agronomic and physiological evaluation.

To analyze agronomic parameters nine plants from each treatment were evaluated at 30 days for the following parameters: plant height, number and leaf length, number and root length, diameter of pseudostem, fresh and dry weight.

For physiological analysis, were evaluated rate of photosynthesis in $\mathrm{CO}_{2} \mathrm{~m}^{-2} \mathrm{~s}^{-1}$, rate of transpiration (E) in $\mathrm{mol} \mathrm{H}_{2} \mathrm{O} \mathrm{m}^{-2} \mathrm{~s}^{-1}$ and stomata conductance (gs) in mol m $\mathrm{m}^{-2} \mathrm{~s}^{-1}$ using gas exchange analyzer with infrared IRGA (Infra-Red Gas Analyzer model LI-6400). For this analysis, three leaves per treatment were used and the flow density of photo synthetically active photon was fixed in the camera of the equipment in $100 \mu \mathrm{mol}$ de photons $\mathrm{m}^{-}$ ${ }^{2} \mathrm{~s}^{-1}$ with the use of artificial source.

After the data was recorded, the data analysis was performed using the statistical analysis software Sisvar (FERREIRA, 2011). The analysis of variance test at $5 \%$ probability and mean comparison were performed for qualitative data whereas the regression analysis was performed for the quantitative data.

\section{RESULTS AND DISCUSSION}

The analysis of variance showed significance difference for all agronomic and physiological variables among cultivars. None of the agronomic variables are significant for the factor compaction simulated by Phytagel. Among the physiological variables rate of photosynthesis presented significant interaction between the two factors evaluated.

The significance of agronomic variables among cultivars can be observed in Figure 1. It also observed that the cultivar Grand Naine presented superior development for all the agronomic variables in relation to cultivars BRS Vitória and BRS Princesa. Such results suggested agronomically the cultivar Grand Naine presented superior vigor over other cultivars evaluated.

Regarding the root length, it is important to emphasize that the roots of the banana cultivars did not penetrate the most consistent media. In these media, the roots grew between the media and the wall of the tube, or in the less consistent upper layer.

In relation to physiological variables, the rate of photosynthesis showed significant interaction among the factors for cultivar Grand Naine as presented in Figure 2.

The rate of photosynthesis in cultivar Grand Naine increased linearly and proportionally with the increase of compaction stress. Such behaviour is probably the mechanism to overcome the stress condition. In other word, cultivar Grand Naine accelerates its metabolism of synthesis to tolerate the stress. From this fact, it is possible to infer the cultivar has probable tolerance for the stress. Possibly due to this reason, the variety Grand Naine did not show negative response agronomically in the presence of different level of compactions. To increase the rate of photosynthesis probably the cultivar Grand Naine increase biomass production and compensate the deficit occurred due to stress. 


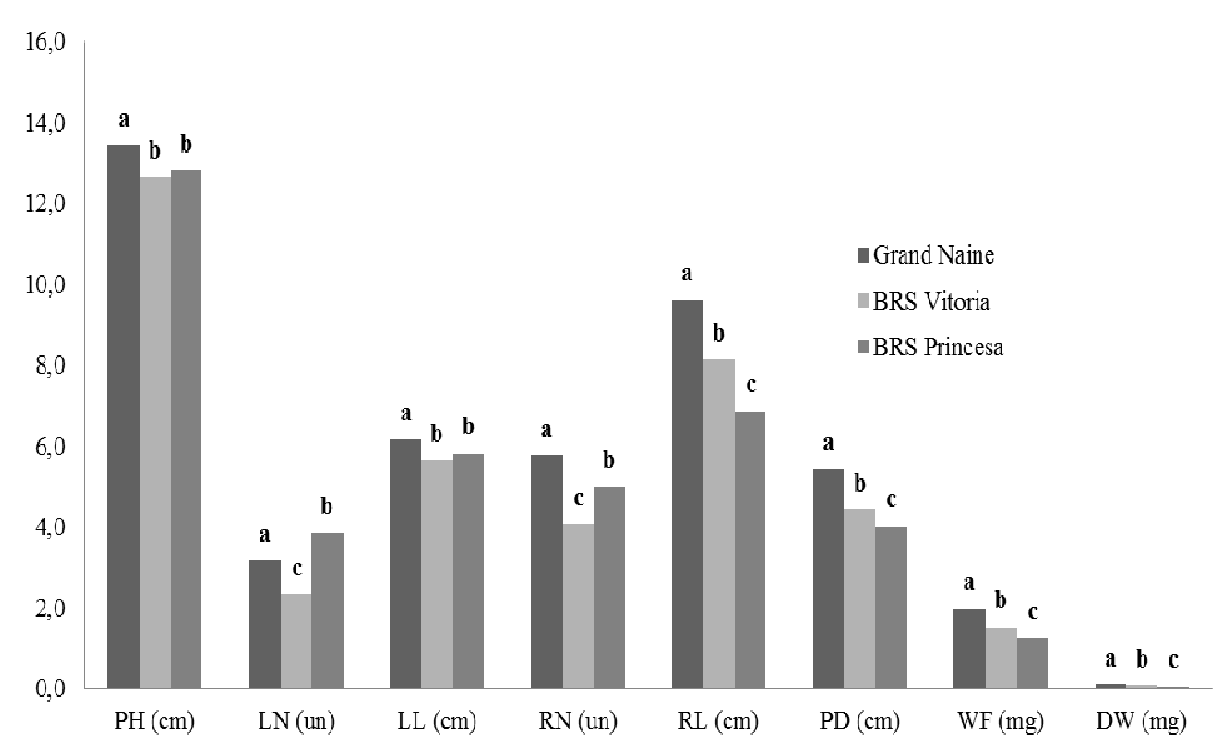

Figure 1. Behavior of variables agronomic: plant height (PH), leaves number (LN), leaf length $(\mathrm{LL})$, roots number $(\mathrm{RN})$, root length $(\mathrm{RL})$, pseudostem diameter (PD) weight fresh (WF) and dry weight (DW), depending on the Grand Naine, BRS Vitória and BRS Princesa varieties, under different compressions simulated by Phytagel doses. * Means followed by the same letters are not significantly different among them at $5 \%$ level of probability using Scott-Knott test.

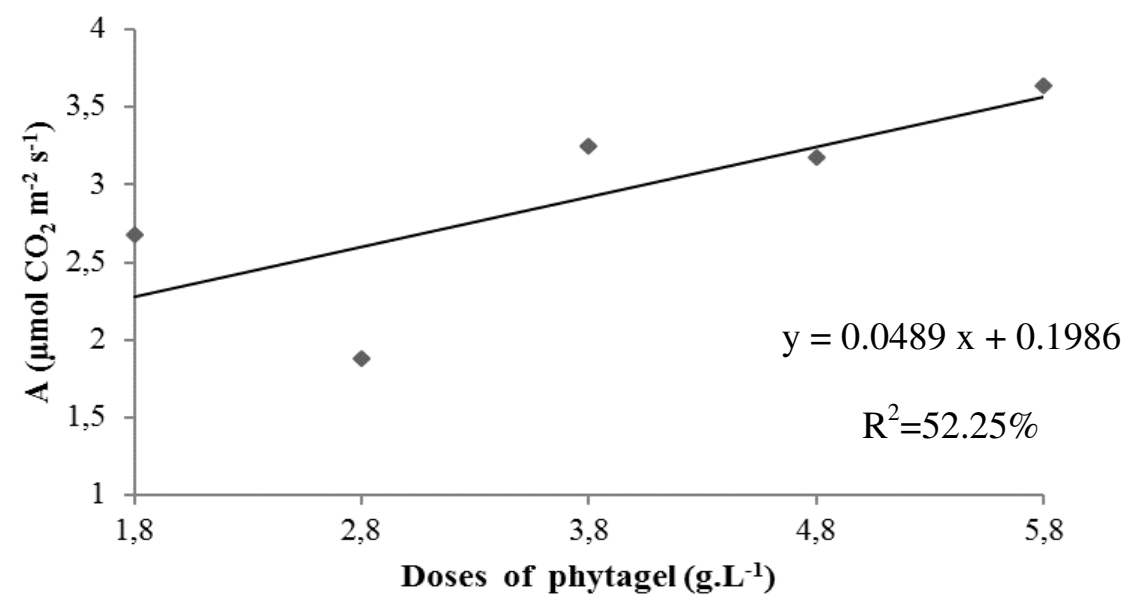

Figure 2. Rate of photosynthesis (A) in $\mu \mathrm{mol} \mathrm{CO}_{2} \mathrm{~m}^{-2} \mathrm{~s}^{-1}$ for cultivar Grand Naine in function of different compactions simulated by Phytagel dosses.

Therefore, the effects of stress through compaction are not observed on agronomic variables due to the plant physiological capacity to overcome the stress. Normally plants reduced its photosynthesis with some type of stress as observed in eucalyptus in edaphoclimatic condition of drought (TATAGIBA et al., 2015). In contrast, the cultivar Grand Naine increase its photosynthesis with the abiotic stress condition. Therefore, from this compartment it is possible to infer the cultivar Grand Naine is tolerant to stress condition provided in this study.

In relation to variables stomatal conductance and transpiration significance difference was observed only for the factor cultivar (Figure 3). Among the three cultivars again superior performance was observed by cultivar Grand Naine. The cultivar Grand Naine presented the highest 
stomatal conductance in comparison to other cultivars in this study (Figure 3A). This implies high carbon assimilation and consequently high biomass production the fact that can explain superior agronomic performance obtained over other cultivars. The occurrence of high rate of transpiration by the same cultivar (Figure 3B) also prove its superiority since transpiration facilitate the absorption and assimilation of nutrients from the culture medium to the plant body by favoring high biomass accumulation as observed previously in agronomic variables evaluations.

(A)

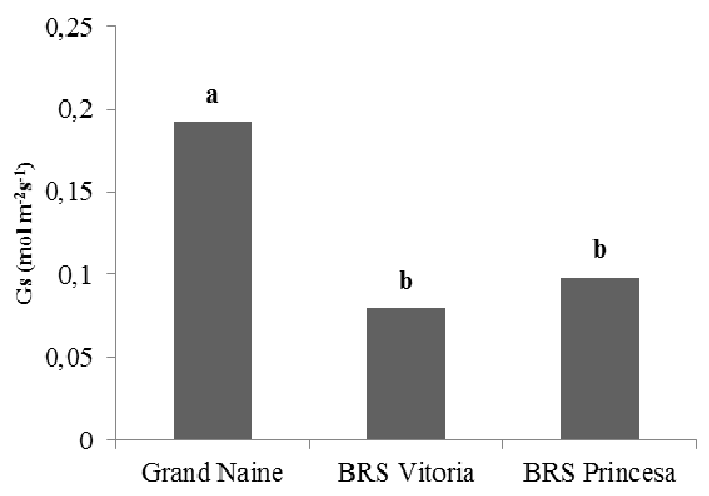

(B)

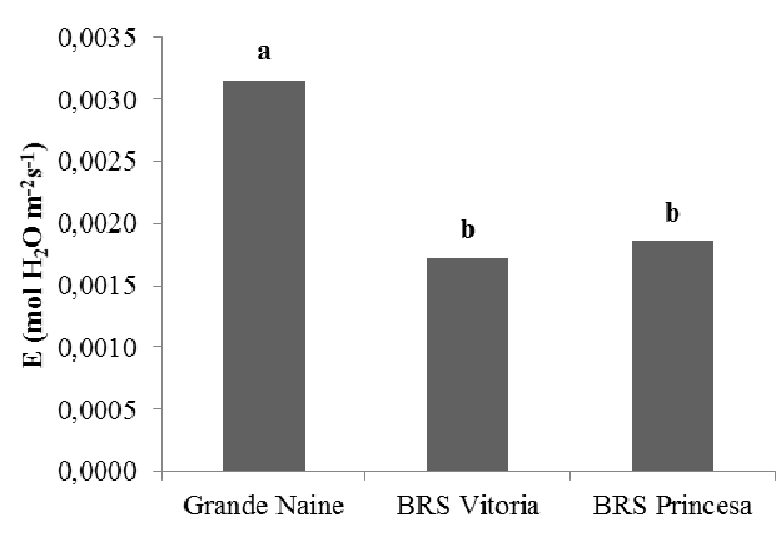

Figure 3. Physiological variables: A - Stomata conductance (Gs) in $\mathrm{mol} \mathrm{m}^{-2} \mathrm{~s}^{-1}$ and $\mathrm{B}$ - rate of transpiration (E) in mol $\mathrm{H} 2 \mathrm{O} \mathrm{m}^{-2} \mathrm{~s}^{-1}$ in function of cultivars Grand Naine, Vitória and Princesa, submitted in different simulated compaction by Phytagel. * Means followed by the same letter did not showed significant difference among them at $\mathrm{P}<0.05$, using Scott-Knott mean separation test.

From its superiority for the rate of photosynthesis, stomata conductance and transpiration observed by the cultivar Grand Naine, it's possible to concluded that this variety has synthesis metabolism ability. Such physiological behavior collaborates with its high agronomic performance since with high level of gas exchange resulted high availability of energy for the synthesis of plant biomass.

The variables of gas exchange are constantly considered as an important parameter in research work on abiotic stress. Sousa et al. (2016) observed the inhibition of gas exchanges in irrigated citrus with saline water and Cerqueira et al. (2015) observed that the gas exchange in Vitts was negatively affected by water stress. However, the quantification of gas exchange in relation to stress by compaction is variable that still not mentioned in the literature for banana culture that supports the present work. The other importance of the results on simulated compaction reported here is make available information to establish these banana cultivars in the field.

This information also can be utilized directly in research works that aim in pre-selection of genotypes tolerant to stress (Sakhanokho e Kelley, 2009). According to Anwar et al. (2010) the simulation technique in vitro can be used in the 
breeding program to select genotypes or in acclimatization process of banana plant in vitro before transfer to the field. According to Patade et al. (2009) the constant exposition of plants for factors of biotic and abiotic stress can be done with the objective of making the plant more tolerant when exposed to the new cycle of stress.

\section{CONCLUSION}

The cultivar Grand Naine prove superior over cultivars BRS Vitória and BRS Princesa under the simulated in vitro compaction.

\section{ACKNOWLEDGEMENTS}

The authors would like to thank Coordination of Improvement of Higher Education Personnel (CAPES), National Council for Scientific and Technological Development (CNPq) and Minas Gerais Research Foundation (FAPEMIG) for the project funding and scholarships.

RESUMO: A bananicultura é uma atividade agrícola difundida em diferentes áreas e constantemente sujeita a estresses abióticos, os quais limitam sua produtividade. Para sanar o efeito dos estresses abióticos pesquisas podem ser simuladas in vitro, pois devido à característica de ambiente controlado pode proporcionar efeito puro do fator de estresse. Sendo assim, o objetivo do presente trabalho foi simular a compactação em bananeiras cultivadas in vitro mediante o uso de Phytagel. Para instalação do experimento utilizou-se o meio de cultura MS em duas consistências distintas, adicionadas a tubos de ensaios. Na parte inferior desses, adicionou-se $10 \mathrm{~mL}$ do meio de cultura com distintas consistências de geleificação: 1,$8 ; 2,8 ; 3,8 ; 4,8$ e $5,8 \mathrm{~g} \mathrm{~L}^{-1}$ de Phytagel. Sobre este meio de cultura foi adicionado mais $5 \mathrm{~mL}$ de meio MS, mas na consistência padrão de $1,8 \mathrm{~g} \mathrm{~L}^{-1}$ de Phytagel. Posteriormente foram inoculados propágulos das cultivares Grand Naine, BRS Vitória e BRS Princesa. Aos 30 dias de cultivo o material vegetal foi submetido a avaliações fitotécnicas e fisiológicas. Observa-se que as variáveis fitotécnicas não foram significativas para o fator compactação e que a cultivar Grand Naine obteve maior desempenho nessa característica. Observa-se também que a cultivar Grand Naine aumenta sua taxa fotossintética mediante a compactação. Esse comportamento provavelmente ocorre visando a superação desse estresse e explica porque as variáveis fitotecnicas não são comprometidas. Portanto, conclui-se que a cultivar Grand Naine é superior as cultivares BRS Vitória e BRS Princesa, porque mediante a simulação de compactação apresenta superioridade em taxa fotossintética, condutância estomática e transpiração, favorecendo o acumulo de biomassa vegetal.

PALAVRAS-CHAVE: Musa sp. Estresse abiótico. Cultura de tecidos. Phytagel

\section{REFERENCES}

ANWAR, N.; KIKUCHI, A.; WATANABE, K. N. assessment of somaclonal variation for salinity tolerance in sweet potato regenerated plants. African Journal of Biotechnology, v. 9, n. 43, p. 7256-7265, 2010.

CERQUEIRA, R. C.; COSTA, J. M.; CHAVES, M. M.; RODRIGUES, J. D. Fisiologia e metabolismo foliar em duas variedades de videira sujeitas a um ciclo de défice hídrico e reidratação. Revista Brasileira de Ciências Agrárias. v. 10, n. 2, p. 211-217. 2015. https://doi.org/10.5039/agraria.v10i2a5045

CHAMPION, J. Le bananier: collection techiniques agricoles et productions tropicales, GP Maiosonneuve et Larose, Paris, 1963. 263 p.

CLAYES, H.; LANDEGHEM, S.V.; DUBOIS, M.; MALEUX, K.; INZÉ, D. What is stress? dose-response effects in commonly used in vitro stress assays. Plant Physiology, v. 165, n. 1, p. 519-517, 2014. https://doi.org/10.1104/pp.113.234641

EMBRAPA - Empresa Brasileira De Pesquisa Agropecuária. Banana BRS Princesa. 2008. Available in: $<$ https://www.embrapa.br/mandioca-e-fruticultura/busca-de-produtos-processos-e-servicos/-/produtoservico/1432/banana-brs-princesa>. Access in: April 26, 2016. 
EMBRAPA - Empresa Brasileira De Pesquisa Agropecuária. Banana BRS Vitória. 2005. Available in: $<$ https://www.embrapa.br/busca-de-produtos-processos-e-servicos/-/produto-servico/1534/banana-brs-vitoria>. Access in: April 26, 2016.

EMBRAPA- Empresa Brasileira De Pesquisa Agropecuária. Banana Grand Naine. 2003. Available in: $<$ http://sistemasdeproducao.cnptia.embrapa.br/FontesHTML/Banana/BananaRondonia/cultivares.htm>. Access in: April 26, 2016.

FERREIRA, D. F. Sisvar: a computer statistical analysis system. Ciência e Agrotecnologia, v. 35, n. 6, p. 1039-1042. 2011. https://doi.org/10.1590/S1413-70542011000600001

GILL, S. S.; TUTEJA, N. Reactive oxygen species and antioxidant machinery in abiotic stress tolerance in crop plants. Plant Physiology and Biochemistry, v. 48, n. 12, p. 909-930, 2010.

https://doi.org/10.1016/j.plaphy.2010.08.016

GODEFROY, J. Le développemente des racines du bananier dans divers sols: relation avec la fertilité. Fruits, v. 24, n. 2, p. 101-104, 1969.

LAWLOR, D. W. Genetic engineering to improve plant performance under drought: physiological evaluation of achievements, limitations, and possibilities. Journal of Experimental Botany, v. 64, n. 1, p. 83-108, 2013. https://doi.org/10.1093/jxb/ers326

MURASHIGE T, SKOOG FA. A revised medium for a rapid growth and bioassays with tobacco tissues cultures. Plant Physiology, v. 15, n. 1, p. 473-479, 1962. https://doi.org/10.1111/j.1399-3054.1962.tb08052.x

PATADE, V. Y.; BHARGAVA, S.; SUPRASANNA, P. Halopriming imparts tolerance to salt and PEG induced drought stress in sugarcane. Agriculture, Ecosystems and Environment, v. 134, p. 24-28, 2009. https://doi.org/10.1016/j.agee.2009.07.003

RAVI, I.; VAGANAN, M.M. Abiotic Stress Tolerance in Banana. In book: Abiotic Stress Physiology of Horticultural Crops, India, 2016, chapter 12, pp. 207-222. https://doi.org/10.1007/978-81-322-2725-0_12

SAKHANOKHO, H. F.; KELLEY, R. Y. Influence of salicyclic acid on in vitro propagation and salt tolerance in Hibiscus acetosella and Hibiscus moscheutos (cv. 'Luna Red'). African Journal of Biotechnology, v. 8, n. 8, p. 1474-1481, 2009.

SILVA, L. M. S.; OZIER-LAFONTAINE; TOURNEBIZE. As potencialidades da associação da banana (Musa acuminata cultivar cavendish "grande nane") com o feijão-de-porco (Canavalia ensiformis). Revista Brasileira de Agroecologia, v. 1, p. 49-52, 2006.

SOUSA, J.R.M.; GHEYI, H.R.; BRITO, M.E.B.; XAVIER, D.A.; FURTADO, G.F. impact of saline conditions and nitrogen fertilization on Citrus production and gas exchanges. Revista Caatinga, v. 29, n. 2, p. 415, 2016. https://doi.org/10.1590/1983-21252016v29n218rc

TATAGIBA, S.D.; PEZZOPANE, J.E.M.; REIS, E.F. Fotossíntese em eucalyptus sob diferentes condições edafoclimáticas. Engenharia na agricultura, v. 23 n. 4, p. 336-345 2015. https://doi.org/10.13083/14143984/reveng.v23n4p336-345 